\title{
Career Incentives of Local Leaders and Residential Land Transfer in China
}

\author{
Yaqi Sun \\ Guanghua School of Management, Peking University, Beijing, China \\ Email: sunyaqi@pku.edu.cn
}

How to cite this paper: Sun, Y. Q. (2020). Career Incentives of Local Leaders and Residential Land Transfer in China. Modern Economy, 11, 1245-1262. https://doi.org/10.4236/me.2020.117089

Received: June 10, 2020

Accepted: July 11, 2020

Published: July 14, 2020

Copyright $\odot 2020$ by author(s) and Scientific Research Publishing Inc. This work is licensed under the Creative Commons Attribution International License (CC BY 4.0).

http://creativecommons.org/licenses/by/4.0/

\begin{abstract}
This study investigates the impact of career incentives of local leaders on China's residential land transfer. It constructs the measure of career incentives of local leaders by utilizing a large resume dataset of 1266 city leaders in 292 Chinese cities from 2000 to 2014 according to the method used by Wang et al. (2019). Matching the city leaders data with the residential land transfer data from 2006 to 2014 in 46 Chinese cities, our empirical results show that one-standard-deviation increase in a local leader's career incentive will lead to $12.29 \%$ decrease in residential land transfer area, $27.35 \%$ increase in residential land transfer price, $20.05 \%$ increase in residential land transfer revenue and $2.99 \%$ increase in the ratio of areas transferred through auction to all transferred residential land areas.
\end{abstract}

\section{Keywords}

Residential Land Transfer, Career Incentives of City Leaders, China, Political Economy

\section{Introduction}

With China's rocketing economic development and rapid urbanization, land plays a critical part in boosting economic growth and improving urban residents' welfare. In China's current state-owned land system, central government and provincial governments formulate the land development plans but don't transfer land directly. Local city governments have the monopoly rights in local land development and land transfer and can manipulate the land transfer to achieve certain policy goals

Since Fiscal reform in 1994, China's central government has obtained more financial resources and local city governments have faced the problem of insufficient fiscal revenues, under this circumstance, city governments have become 
increasingly dependent on land-transfer revenue to take their responsibility of providing urban public goods, which in turn can stimulate local economic growth. From 2000 to 2017, land transfer area has grown from 48,400 hectares to 230,900 hectares, and the land transfer revenue has exceeded CNY5.00 trillion by 2017, equaling to $6.34 \%$ of China's GDP by that time. And residential land transfer revenue accounts for nearly $75 \%$ of total land transfer revenue (Wang et al., 2019), which means the residential land transfer has been a nonnegligible tool for city-level governments to relieve fiscal pressure, provide public goods and improve local economic performance. Meanwhile, residential land transfer can partially explain China's rapid development of real estate market and booming housing price which heavily affects the economic development and social welfare of local residents. Considering that, we focus on the residential land transfer behavior of city-level governments and investigate the factors that have impact on it.

This study investigates a pivotal driver of residential land transfer in China: career incentives of local leaders. We pay attention to the career incentives of local leaders because of two highly important institutional characteristics concerning about China's land development.

Firstly, China's political system is centralized, the administrative structure consists of four layers in China and the city leaders are in fierce promotion tournaments in which the upper level governments reward and punish the city leaders according to the outcome of cities' economic condition, such as GDP, GDP growth rate and fiscal revenues (Qian \& Xu, 1993; Maskin et al., 2000; Li \& Zhou, 2005; Xu, 2011). In order to increase promotion likelihood, the city leaders take a variety of measures to facilitate local economic development. It is worth mentioning that the city's key leader is its party secretary not its city mayor or province governor. So, when we mention the city leader, it refers to the city's secretary. Secondly, local governments take the responsibility of providing public goods such as health care, basic education and infrastructure and they make and implement local economic policies. So, city leaders have dominant power on the local economic issues in China, including the land development. They can decide not only the area of land to be developed but also the use type, transaction type and reservation price of the land parcels to be sold. Considering these two features, it is fairly reasonable to believe that city leaders have strong incentives and capabilities to manipulate local land transfer to get revenues and boost local investments.

Unlike recent literature which treats all types land as whole to conduct research on local governments' land transfer behavior or focus mainly on industrial land transfer (Lichtenberg \& Ding, 2009; He et al., 2014; Yu et al., 2015), this paper specifies in the study on the residential land transfer behavior of local governments. Meanwhile, unlike the previous studies of residential land transfer which treat the fiscal incentive as the key motivation of residential land transfer (Han \& Kung, 2015), our study emphasizes the effect the career incentives of local leaders. 
We construct the measure of career incentives of local leaders by utilizing a large resume dataset of 1266 incumbent city leaders from 2000 to 2014 in 292 cities of China according to the method used by Wang et al. (2019). Then we use data of residential land transfer in 46 Chinese cities from 2006 to 2014 to empirically test how city leaders' career incentives affect the residential land transfer area, transfer price, transfer revenue and the ratio of areas transferred through auction to all residential land areas. Our empirical results show that one-standard-deviation increase in a local leader's career incentive will result in $12.29 \%$ decrease in residential land transfer area, $27.35 \%$ increase in residential land transfer price, $20.05 \%$ increase in residential land transfer revenue and $2.99 \%$ increase in the ratio of areas transferred through auction to all transferred residential land areas. Our study contributes to the existing literature about China's land finance and land development.

There exist obvious differences between the paper of Wang et al. (2019) and ours. Wang et al. (2019) emphasizes the impact of city leaders' career incentives on the spatial structure of residential land while our study focuses on how city leaders' career incentives affect their residential land transfer behavior from the perspectives of quantity, price and transaction type.

The rest of the paper is organized in the following way. Section 2 gives a literature review. Section 3 shows the theoretical analysis and research hypothesis. Section 4 discusses the data and the main variables. In Section 5, we present the econometric model and results of empirical analysis. Section 6 shows a conclusion.

\section{Literature Review}

There exists a variety of literature about the behavior of local city governments in land transfer and urban land development in China (Lichtenberg \& Ding, 2009; Han \& Kung, 2015; Brueckner et al., 2017; Wang et al., 2019). Some scholars treat land transfer, especially the industrial land transfer, as a usual tool to compete for investment and stimulate economic growth to enhance the city leader's promotion chances (Zhang et al. 2011; Wang et al., 2013; Huang \& Du, 2017). The industrial enterprise is highly sensitive to the cost; therefore, the local governments provide the industrial land at low price to attract and retain investment (He et al., 2014; Fan \& Mo, 2014).

Meanwhile, some scholars believe that the local governments' motivation of land transfer is to maximize the land transfer revenue (Yang et al., 2015; Wang \& Hui, 2017). Since fiscal reform in 1994, China's central government has increased its share of tax revenues and the revenue for local governments has fallen dramatically. Therefore, local governments are more dependent on off-budget revenue to relieve fiscal pressure and achieve policy goals (Eckaus, 2003; Wong \& Bird, 2008; Tao et al., 2010). Since the local governments enjoy the monopoly rights in providing land, the land transfer revenue, especially the commercial land and residential land transfer revenue, becomes an easy vehicle to obtain 
off-budget revenue. Han and Kung (2015) find that the fiscal pressure has positive impact on the area and revenue of residential and commercial land transfer.

Since the local governments transfer different types of land to achieve different policy goals, land transfer has a remarkable influence on China's development. On the one hand, local governments' land transfer stimulates China's economic growth and urbanization process (Lin \& Yi, 2011; He et al., 2016; Mo, 2018; Wang et al. 2019). On the other hand, a lot of problems follow. Some land transfer cases are inherently corrupted (Cai et al., 2013; Chen \& Kung, 2019), which causes efficiency losses and welfare losses in China.

\section{Theoretical Analysis and Research Hypothesis}

Since 1998, China has constructed a land quota system. In this system, the central government formulates the long-run land development plan which specifies the minimum agricultural land areas and the maximum newly exploitable land areas for each province. That is, central government allocates the land quartos to each province. Then the province governments formulate their own land development plan in both long and short term and allocate the land quotas to each city. Constrained by land quotas, a local city government is a monopolist in the local land transfer market and the city leader holds critical control over local land development.

In China's current political system, the upper level governments evaluate the local city leaders and the local economic condition is the vital indicator for evaluating. Local leaders are in fierce promotion tournaments. Meanwhile, a city leader has ex-ante promotion likelihood and it is determined by some characteristics that he has when he stars his office, such as age, hierarchical level, educational attainment and previous working experience and has nothing to do with his later experience and performance. Under this circumstance, the ex-ante promotion likelihood could be used to measure the local leader's career incentive because the higher the ex-ante promotion likelihood is, the higher the career incentive is; the higher the career incentive is, the more weight the city leader puts on local economic growth.

Given these conditions, the local leaders have incentives and capabilities to manipulate the local land transfer to enhance his promotion chances. Since the industrial land is mainly used to attract investment and promote economic development directly, local leaders with higher career incentives prefer to oversupply the industrial land to boost local economic growth. However, the total amount of land that can be transferred is constrained by the land quota, the oversupply of residential land means the undersupply of residential land. Meanwhile, there is a strong or even rigid demand of residential land due to the boom of real estate market in China. Consequently, the reduced supply of residential land will drive the residential land transfer price up. This leads to our first and second testable hypothesis as follows:

Hypothesis 1: All else being equal, the higher career incentive of a local leader 
is, the less area the city government will transfer.

Hypothesis 2: All else being equal, the higher career incentive of a local leader is, the higher the residential land transferring price is.

In China, the price elasticity of demand for residential land is small than 1 . Consequently, the increase of residential land transferring price means the increase of residential land revenue. This leads to our third testable hypothesis as follows

Hypothesis 3: All else being equal, the higher the career incentive of a local leader is, the huger the amount of residential land transfer revenue is

In China, the industrial land allocation is mostly through agreement transfer and the residential land sale is mainly through public transfer who includes tree transfer types: auction, bidding and listing. The sale price is higher when the land is transferred through auction (Cai et al., 2013). The city leaders whose career incentives are higher want to obtain more land transfer revenue to finance infrastructure investment, which in turn promote economic growth. Considering that, having the intention of acquiring more residential land transfer revenue, the city leaders whose career incentives are higher are preferred more to transfer the residential land through auction. This leads to our fourth testable hypothesis as follows.

Hypothesis 4: All else being equal, the higher the career incentive of a local leader is, the greater the ratio of areas transferred through auction to total transferred residential land areas.

These four hypotheses are all concern about residential land behavior of local governments and are correlated with each other.

\section{Data and Variable}

\subsection{Data}

Our data sample of residential land transfer contains more than 90,000 residential land transactions in 46 Chinese cities from 2006 to 2014. This data is derived from Landchina (https://www.landchina.com/), which is a subordinate website of the" Ministry of Land and Resources" of China. Because the "Ministry of Land and Resources" stipulates that the outcome of each land transaction must be publicized on this website, we could obtain detailed information about each transferred residential land parcel, such as its transaction date, location, sale revenue, sale price, area and the transaction type.

We obtain personal information of the city leaders (that is, the party secretary) to calculate our key independent variable: incentives of local leaders. We cover 292 Chinese cities from 2000 to 2014 to collect the information of 1266 incumbent city leaders. We collect this information mainly from Xinhua (http://www.xinhuanet.com/) and Renmin (http://www.people.com.cn/).

\subsection{Variables}

The dependent variables are residential land transfer area, residential land 
transfer price, residential land transfer revenue and the ratio of areas transferred through auction to total transferred residential land areas.

After dropping the outliers, for each city, we sum up the areas of all residential land parcels annually and obtain the total area of transferred residential land in each city annually. We sum up the revenues of all transferred residential land parcel annually and obtain the residential land transfer revenue in each city annually. Dividing the total revenue by the total area, we have the residential land transfer price.

The key independent variable is career incentives of local leaders. Utilizing the method of Wang et al. (2019), we construct the incentives of local leaders. In China, hierarchical levels for city leaders from bottom to upper level are following: county, prefectural, deputy province and province and we don't include the county level leaders in our sample. The mandatory retirement age is universal in China and it differs with the hierarchical level of a city leader. Therefore, ex-ante promotion likelihood is highly influenced by the hierarchical level and the exact age when a city leader starts to take office. Meanwhile, whether a city leader has a graduate degree and whether a city leader has previous working experience in central government also have impact on his ex-ante promotion likelihood ( $\mathrm{Li} \&$ Zhou, 2005). Consequently, we estimate how a city leader's exact age at start, hierarchical level at start, previous working experience in central government and graduate degree when he takes office influence his promotion likelihood by using our dataset which contains the information of 1266 city leaders from 2000 to 2014 in 292 cities.

The promotion variable, in our definition, is a dummy variable. If a city leader's immediate next position level is higher, it equals 1 . For instance, if a city leader is from a prefecture level position to a deputy-province level position, we define him as being promoted. We need to emphasize that if a city leader's next position was in local "Chinese People's Political Consultative Conference" (CPPCC) or "People's Congress “(PC), we don't think him as being promoted. Meanwhile, if a city leader was dead or dismissed in his office term, we define the promotion dummy as missing. Also, if a city leader was still in his office term at the end of 2019, we can't observe his promotion outcome and define the promotion dummy as missing. In all, we have the promotion outcomes of 1175 city leaders and the number of city leaders who were promoted is 356 . The overall promotion ratio is $30.30 \%$. Table 1 presents the summary description of the 1266 city leaders.

We then run the regression to find the impact of start age, start hierarchical level, graduate degree and the dummy of previous working experience in central government on true promotion outcome. Colum 1 and colum 2 on Table 2 are the LRM results, and column 3 and column 4 show the Probit Results. Column1 and column 3 don't include the dummy variables of graduate degree and central experience while column 2 and colum 4 include (Wang et al., (2019) used the Probit result that excludes the graduate degree and central experience). As is 
Table 1. Summary statistics of 1299 city leaders.

\begin{tabular}{cccc}
\hline city leader characteristics & obs & mean & sd \\
\hline dummy: prefecture & 1.266 & 0.872 & 0.334 \\
dummy: deputy province & 1.266 & 0.115 & 0.319 \\
dummy: province or above & 1.266 & 0.013 & 0.115 \\
start age & 1.266 & 50.252 & 3.992 \\
tenure length, year & 1.246 & 3.803 & 1.802 \\
promotion of city leaders & 1.175 & 0.302 & 0.459 \\
dummy: central experience & 1.266 & 0.052 & 0.222 \\
dummy: graduate degree & 1.266 & 0.669 & 0.471 \\
\hline
\end{tabular}

Table 2. Promotion regression results.

\begin{tabular}{|c|c|c|c|c|}
\hline & \multicolumn{4}{|c|}{ Dummy: promotion } \\
\hline & LPM & LPM & PROBIT & PROBIT \\
\hline VARIABLES & (1) & (2) & (3) & (4) \\
\hline \multirow[t]{2}{*}{ start age } & $-0.037^{\star * *}$ & $-0.034^{* * *}$ & $-0.111^{* * *}$ & $-0.104^{\star * *}$ \\
\hline & $(0.003)$ & $(0.004)$ & $(0.011)$ & $(0.012)$ \\
\hline \multirow[t]{2}{*}{ dummy: deputy-province } & $-2.601^{\star * \star}$ & $-2.634^{* * *}$ & $-9.176^{* * *}$ & $-9.307^{\star * *}$ \\
\hline & $(0.304)$ & $(0.299)$ & $(1.489)$ & $(1.469)$ \\
\hline \multirow[t]{2}{*}{ dummy: province-or-above } & -2.212 & -2.466 & $-6.375^{\star *}$ & $-7.383^{\star * *}$ \\
\hline & $(1.778)$ & $(1.748)$ & $(3.067)$ & $(2.769)$ \\
\hline \multirow[t]{2}{*}{ Start age ${ }^{\star}$ deputy-province } & $0.048^{* * *}$ & $0.048^{* * *}$ & $0.170^{* * *}$ & $0.171^{* * *}$ \\
\hline & $(0.006)$ & $(0.006)$ & $(0.029)$ & $(0.029)$ \\
\hline \multirow[t]{2}{*}{ Start age ${ }^{\star}$ province-or-above } & 0.046 & $0.050^{*}$ & $0.132^{* *}$ & $0.149^{\star * *}$ \\
\hline & $(0.030)$ & $(0.030)$ & $(0.054)$ & $(0.050)$ \\
\hline \multirow[t]{2}{*}{ dummy: graduate degree } & & $0.109^{* * *}$ & & $0.371^{* * *}$ \\
\hline & & $(0.026)$ & & $(0.089)$ \\
\hline \multirow[t]{2}{*}{ dummy: central experience } & & 0.059 & & 0.198 \\
\hline & & $(0.056)$ & & $(0.166)$ \\
\hline \multirow[t]{2}{*}{ Constant } & $2.189^{* * *}$ & $1.965^{* * *}$ & $5.039^{* * *}$ & $4.399^{* * *}$ \\
\hline & $(0.178)$ & $(0.189)$ & $(0.570)$ & $(0.590)$ \\
\hline Observations & 1.175 & 1.175 & 1.175 & 1.175 \\
\hline R-squared & 0.104 & 0.117 & & \\
\hline Pseuddo R-squared & & & 0.088 & 0.101 \\
\hline
\end{tabular}

Note: we employ ${ }^{*},{ }^{* *}$ and $^{* * *}$ respectively to denote the significance level $10 \%, 5 \%$ and $1 \%$ respectively; we report the standard errors clustered at city level.

shown in Table 2, when the two variables are included, the R-square increases, so we should include them. Then the estimated coefficients on start age, start 
hierarchical level, interaction term, graduate degree and central experience in column 4 of Table 2 are used to obtain the predicted promotion likelihood for all 1266 city leaders. As mentioned in Section 2, the higher the predicted promotion likelihood of a city leader is, the higher his career incentive is. Therefore, we use the ex-ante promotion likelihood to measure the career incentive of a city leader.

As is noted, in order to avoid endogeneity problem, we don't include the variables concerning the city's economic development in the promotion regression. Also, there is an argument that city leaders with different career incentives could be systematically appointed to cities with different pre-trend economic performance, for instance, a leader with higher ex-ante likelihood has more chances to be assigned to a city with better economic performance and so he is more likely to stand out in promotion tournament. We address this concern by testing the relationship between the city's GDP and GDP growth rate in the year before the office term of a city leader starts and his career incentive and don't find significant correlation.

We control for a vector of time-varying city-level characteristics that will influence residential land transfer behavior of local governments. These key economic control variables include GDP, GDP growth rate, the proportion of secondary industry, the proportion of tertiary industry, population density, population growth rate, urban ratio, urban residents' per capita disposable income (PCDI), fixed asset investment and urban road area of a city. Also, as mentioned in Section 1, fiscal pressure plays an important role in land transfer behavior of local governments, so we also include fiscal deficit ratio as control variable. It is worth mentioning that we define the fiscal deficit ratio as the proportion of fiscal deficit in fiscal expenditure.

\section{Empirical Analysis}

\subsection{Model}

We investigate how city leaders' career incentives affect the residential land transfer area, transfer price, transfer revenue and the ratio of areas transferred through auction to all transferred residential land areas using city-year level panel data. The main regression specifications are given by

$$
\begin{gathered}
\ln (\text { landarea_resi })_{i t}=\alpha_{0}+\alpha_{1} \text { incentive }_{i t}+X_{i t-1} \beta+\mu_{i}+\eta_{t}+{\text { provinctrend }+\epsilon_{i t}} \\
\ln (\text { landprice_resi })_{i t}=\alpha_{0}+\alpha_{1} \text { incentive }_{i t}+X_{i t-1} \beta+\mu_{i}+\eta_{t}+\text { provinctrend }+\epsilon_{i t} \\
\ln (\text { landprice_resi })_{i t}=\alpha_{0}+\alpha_{1} \text { incentive }_{i t}+X_{i t-1} \beta+\mu_{i}+\eta_{t}+\text { provinctrend }+\epsilon_{i t} \\
\text { aunction_ratio }_{i t}=\alpha_{0}+\alpha_{1} \text { incentive }_{i t}+X_{i t-1} \beta+\mu_{i}+\eta_{t}+\text { provinctrend }+\epsilon_{i t}
\end{gathered}
$$

In above equation, $i$ denotes the city and $t$ denotes the year, landarea_resi ${ }_{i t}$ is the residential land transfer area, landrevenue_resi $i_{i t}$ is the residential land transfer revenue. landprice_resi $i_{i t}$ is the residential land transfer price. aunction_ratio $_{i t}$ is he ratio of areas transferred through auction to all residential land areas. incentive ${ }_{i t}$ is our key independent variable: the career incentive of a 
city leader. $X_{i t-1}$ are the control variables about the social and economic features for city $i$. It is noticeable that the city leaders make decisions based on the previous performance of the city, so we use the lagged city-level control variables. $\mu_{i}$ is city fixed effect, we include city fixed effect to control for some features that don't change with time in city $i$ but may affect the residential land transfer, such as the climate and other nature characteristics. $\eta_{t}$ is the time fixed effect. provincetrend is the province specific time trend. $\epsilon_{i t}$ is the error term. Table 3 reports the summary statistics of these variables.

\subsection{Benchmark Results}

The data we utilized is panel data, so a random effect model and a fixed effect model are used for regression respectively. Hausman's test rejects the null hypothesis, so we mainly show fixed effect regression results. Table 4 reports the baseline results of this paper. Regression result of the residential land transfer area is in Column 1, regression result of the residential land transfer price is in Column 2, column 3 is the regression result of the residential land transfer revenue, and column 4 presents the regression result of the ratio of areas transferred through auction to all residential land areas.

Table 3. Summary statistics.

\begin{tabular}{|c|c|c|c|c|c|}
\hline VARIABLE & obs & mean & sd & $\min$ & $\max$ \\
\hline landarea_resi(hectare) & 408 & 741.782 & 713.943 & 0.802 & 6957.991 \\
\hline landprice_resi(tousand yuan/tectare) & 408 & $20,750.79$ & $22,205.100$ & 0.000 & $266,939.400$ \\
\hline landrevenue_resi(tousand yuan) & 408 & $15,010,146.96$ & $16,831,399.96$ & 0 & $1.04 \mathrm{E}+08$ \\
\hline auction ratio & 408 & 0.111 & 0.168 & 0.000 & 1.000 \\
\hline incentives & 414 & 0.230 & 0.151 & 0.040 & 0.736 \\
\hline fiscak deficit ratio & 414 & 0.209 & 0.171 & -0.541 & 0.661 \\
\hline $\log (\mathrm{GDP})$ & 414 & 7.953 & 0.805 & 5.733 & 9.990 \\
\hline GDP growth rate & 413 & 0.129 & 0.028 & 0.026 & 0.232 \\
\hline proportion of secondary industry & 414 & 0.450 & 0.103 & 0.111 & 0.775 \\
\hline proportion of secondary industry & 414 & 0.495 & 0.099 & 0.217 & 0.859 \\
\hline urban ratio & 414 & 0.549 & 0.171 & 0.233 & 1.000 \\
\hline population rate & 414 & 0.049 & 0.038 & -0.090 & 0.198 \\
\hline $\log$ (population density) & 414 & 6.389 & 0.640 & 4.820 & 8.245 \\
\hline $\log (\mathrm{PCDI})$ & 414 & 9.923 & 0.374 & 9.072 & 10.749 \\
\hline $\log ($ fixed asset investment) & 414 & 7.318 & 0.809 & 4.921 & 9.219 \\
\hline $\log ($ urban road area) & 414 & 8.057 & 0.741 & 6.314 & 9.975 \\
\hline dummy: PPC & 414 & 0.222 & 0.416 & 0.000 & 1.000 \\
\hline dummy: PPCpre1 & 414 & 0.222 & 0.416 & 0.000 & 1.000 \\
\hline dummy: PPCpre2 & 414 & 0.213 & 0.410 & 0.000 & 1.000 \\
\hline dummy: PPCpost1 & 414 & 0.324 & 0.468 & 0.000 & 1.000 \\
\hline dummy: PPCpost2 & 414 & 0.314 & 0.465 & 0.000 & 1.000 \\
\hline
\end{tabular}


Table 4. Baseline regression results.

\begin{tabular}{|c|c|c|c|c|}
\hline & $\ln$ (landarea_res & landprice_resi) & $\ln ($ landrevenue_resi) & auction ratio \\
\hline independent variable & (1) & (2) & (3) & (4) \\
\hline \multirow[t]{2}{*}{ career incentive } & $-0.958^{\star *}$ & $1.834^{\star *}$ & $1.355^{\star}$ & $0.201^{\star * *}$ \\
\hline & $(0.438)$ & $(0.756)$ & $(0.788)$ & $(0.071)$ \\
\hline \multirow[t]{2}{*}{ fiscal deficit ratio } & 0.305 & -0.88 & $2.586^{* * *}$ & 0.000 \\
\hline & $(0.520)$ & $(0.896)$ & $(0.933)$ & $(0.084)$ \\
\hline \multirow[t]{2}{*}{ GDP } & -0.319 & $2.950^{* *}$ & 2.102 & -0.076 \\
\hline & $(0.765)$ & $(1.319)$ & $(1.376)$ & $(0.124)$ \\
\hline \multirow[t]{2}{*}{ GDP growth rate } & 0.910 & -1.727 & -1.725 & -0.325 \\
\hline & $(2.509)$ & $(4.326)$ & $(4.559)$ & $(0.406)$ \\
\hline \multirow[t]{2}{*}{$\begin{array}{c}\text { proportion of } \\
\text { secondary industry }\end{array}$} & -2.008 & -5.876 & -7.527 & $-1.366^{\star *}$ \\
\hline & $(3.496)$ & $(6.021)$ & $(6.269)$ & $(0.565)$ \\
\hline \multirow[t]{2}{*}{$\begin{array}{c}\text { proportion of } \\
\text { secondary industry }\end{array}$} & 2.205 & 0.024 & 0.933 & -0.507 \\
\hline & (3.019) & $(5.196)$ & $(5.403)$ & $(0.488)$ \\
\hline \multirow[t]{2}{*}{$\ln$ (fixed asset investment) } & 0.364 & -0.406 & -0.865 & -0.013 \\
\hline & $(0.322)$ & $(0.557)$ & $(0.581)$ & $(0.052)$ \\
\hline \multirow[t]{2}{*}{ urban ratio } & $1.540^{*}$ & -2.538 & -2.373 & 0.181 \\
\hline & $(0.894)$ & $(1.579)$ & $(1.740)$ & $(0.144)$ \\
\hline \multirow[t]{2}{*}{ population growth rate } & 0.511 & 1.743 & 2.384 & -0.488 \\
\hline & $(1.896)$ & $(3.258)$ & $(3.399)$ & $(0.307)$ \\
\hline \multirow[t]{2}{*}{$\ln$ (population density) } & $1.058^{\star *}$ & $1.460^{* *}$ & 0.608 & -0.012 \\
\hline & $(0.413)$ & $(0.713)$ & $(0.741)$ & $(0.067)$ \\
\hline \multirow[t]{2}{*}{$\ln (\mathrm{PCDI})$} & 0.260 & -0.255 & 0.080 & $0.259^{*}$ \\
\hline & $(0.911)$ & $(1.569)$ & $(1.633)$ & $(0.147)$ \\
\hline \multirow[t]{2}{*}{$\ln ($ urban road area) } & $0.523^{* *}$ & 0.013 & 0.276 & 0.017 \\
\hline & $(0.245)$ & $(0.434)$ & $(0.476)$ & $(0.040)$ \\
\hline city fixed effect & yes & yes & yes & yes \\
\hline time fixed effect & yes & yes & yes & yes \\
\hline $\begin{array}{l}\text { province specific } \\
\text { time trend }\end{array}$ & yes & yes & yes & yes \\
\hline \multirow[t]{2}{*}{ constant } & -78.095 & $226.195^{\star *}$ & 115.744 & $15.128^{*}$ \\
\hline & $(50.082)$ & $(88.767)$ & $(92.738)$ & $(8.096)$ \\
\hline observations & 408 & 404 & 404 & 408 \\
\hline R-squared & 0.595 & 0.399 & 0.619 & 0.111 \\
\hline number of city & 46 & 46 & 46 & 46 \\
\hline
\end{tabular}

Note:, we employ ${ }^{*},{ }^{* *}$ and ${ }^{* * *}$ respectively to denote the significance level $10 \%, 5 \%$ and $1 \%$ we report the standard errors clustered at province level. 
Firstly, we analyze the regression result of residential land transfer area. Controlling for other factors, the coefficient of career incentive is significantly negative, suggesting that the residential land transfer area is lower when the city's leader has a higher career incentive. As the career incentive increases one standard deviation, $12.29 \%$ decrease in residential land transfer area follows. As for the control variables, urban ratio, population density and urban road areas have positive effect on the residential land transfer area.

Also, we analyze the regression result of residential land transfer price. Controlling for other factors, the coefficient of career incentive is significantly positive, suggesting that the residential land transfer price is higher in the city with its city leader's career incentive being higher. As the career incentive increases one standard deviation, $27.35 \%$ increase in residential land transfer price follows. As for the control variables, the coefficients of GDP and population density are positive and significant.

Then, we analyze the regression result of residential land transfer revenue. Controlling for other factors, the coefficient of career incentive is significantly positive, suggesting that the residential land transfer revenue is higher in cities with higher career incentives of local leaders. As the career incentive increases one standard deviation, $20.05 \%$ increase in residential land transfer revenue follows. As for the control variables, only fiscal deficit ratio has significant effect on the residential land transfer revenue.

Finally, we analyze the regression result of the ratio of areas transferred through auction to all residential land areas. Controlling for other factors, the coefficient of career incentive is significantly positive, suggesting that a city leader whose higher career incentive is higher prefers to employ the auction to transfer the residential land use right. As the career incentive increases one standard deviation, $2.99 \%$ increase in the ratio of areas transferred through auction to all residential land areas follows. As for the control variables, the coefficients of proportion of secondary industry and per-capita disposable income are significant.

\subsection{Robustness Check}

\subsubsection{Political Business Cycles in China}

There is a concern that a city leader's residential land transfer behavior may be affected by the political business cycles in China. The political business cycles usually mean the cycles of People's Congress of Communist Party (PCCP). In China, every five years, each provincial administrative region holds a PCCP, which is exogenously determined and can be predicted. In PCCP, politicians are elected. If a city has good economic performance, its city leader has more chances to be promoted in the PCCP. Therefore, city leaders may manipulate the residential land transfer to enhance their promotion likelihood according to the political business cycles. Considering that, we control for the effect of political business cycles in China. The regression specification is as follows. 


$$
\begin{aligned}
& \ln (\text { landarea_resi })_{i t}=\alpha_{0}+\alpha_{1} \text { incentive }_{i t}+\text { PPCpre } 2+\text { PPCpre } 1+\text { PPC } \\
& + \text { PPCpost1 }+X_{i t-1} \beta+\mu_{i}+\eta_{t}+\text { provinctrend }+\epsilon_{i t} \\
& \ln (\text { landprice_resi })_{i t}=\alpha_{0}+\alpha_{1} \text { incentive }_{i t}+\text { PPCpre } 2+\text { PPCpre1 }+ \text { PPC } \\
& + \text { PPCpost1 }+X_{i t-1} \beta+\mu_{i}+\eta_{t}+\text { provinctrend }+\epsilon_{i t} \\
& \ln (\text { landrevenue_resi })_{i t}=\alpha_{0}+\alpha_{1} \text { incentive }_{i t}+\text { PPCpre } 2+\text { PPCpre1 }+ \text { PPC } \\
& + \text { PPCpost1 }+X_{i t-1} \beta+\mu_{i}+\eta_{t}+\text { provinctrend }+\epsilon_{i t} \\
& \ln (\text { auction_ratio })_{i t}=\alpha_{0}+\alpha_{1} \text { incentive }_{i t}+\text { PPCpre } 2+\text { PPCpre } 1+\text { PPC } \\
& + \text { PPCpost1 }+X_{i t-1} \beta+\mu_{i}+\eta_{t}+\text { provinctrend }+\epsilon_{i t}
\end{aligned}
$$

PPCpre2, PPCpre1, PPC and PPCpost1 are dummy variables, their descriptive statistics results are demonstrated in Table 3. These dummy variables are used to indicate the political business cycles in China. PPC equals 1 if Provincial

\begin{tabular}{|c|c|c|c|c|}
\hline & $\ln$ (landarea_resi) & $\ln$ (landprice_resi) & $\ln ($ landrevenue_resi) & auction ratio \\
\hline independent variable & (1) & (2) & (3) & (4) \\
\hline \multirow[t]{2}{*}{ career incentive } & $-0.946^{* *}$ & $1.873^{* *}$ & $1.473^{*}$ & $0.031^{\star * *}$ \\
\hline & $(0.440)$ & $(0.761)$ & $(0.789)$ & $(0.011)$ \\
\hline \multirow[t]{2}{*}{ PPCpre2 } & 0.064 & 0.126 & 0.192 & 0.017 \\
\hline & $(0.138)$ & $(0.237)$ & $(0.245)$ & $(0.022)$ \\
\hline \multirow[t]{2}{*}{ PPCpre1 } & -0.139 & -0.059 & -0.242 & 0.057 \\
\hline & $(0.238)$ & $(0.412)$ & $(0.427)$ & $(0.038)$ \\
\hline \multirow[t]{2}{*}{ PPC } & 0.091 & 0.178 & 0.261 & 0.016 \\
\hline & $(0.159)$ & $(0.275)$ & $(0.284)$ & $(0.026)$ \\
\hline \multirow[t]{2}{*}{ PPCpost1 } & 0.060 & 0.099 & 0.122 & 0.008 \\
\hline & $(0.150)$ & $(0.259)$ & $(0.269)$ & $(0.024)$ \\
\hline \multirow[t]{2}{*}{ fiscal deficit ratio } & 0.351 & -0.835 & $2.493^{* * *}$ & -0.015 \\
\hline & $(0.525)$ & $(0.908)$ & $(0.940)$ & $(0.085)$ \\
\hline \multirow[t]{2}{*}{ GDP } & -0.335 & $2.928^{* *}$ & 2.063 & -0.072 \\
\hline & $(0.767)$ & $(1.326)$ & $(1.375)$ & $(0.124)$ \\
\hline \multirow[t]{2}{*}{ GDP growth rate } & 1.104 & -1.314 & -1.071 & -0.298 \\
\hline & $(2.522)$ & $(4.360)$ & $(4.569)$ & $(0.408)$ \\
\hline $\begin{array}{c}\text { proportion of } \\
\text { secondary industry }\end{array}$ & -2.447 & -6.398 & -8.517 & $-1.351^{* *}$ \\
\hline
\end{tabular}
Congress of Communist Party (PCCP) was held in this year, otherwise it equals 0 . PPCpre 2 equals 1 if PCCP would be held two years later, otherwise it equals 0 . PPCpre1 equals 1 if PCCP would be held in one year later, otherwise, it equals 0 . PPCpost 1 equals 1 if PCCP was held one year ago, otherwise it equal 0.

Table 5 shows this robustness check results; the main results are highly robust when the political cycle variables are included.

Table 5. Regression results of including the political business cycles. 


\section{Continued}

\begin{tabular}{|c|c|c|c|c|}
\hline & $(3.511)$ & $(6.056)$ & $(6.274)$ & $(0.568)$ \\
\hline \multirow[t]{2}{*}{$\begin{array}{c}\text { proportion of } \\
\text { secondary industry }\end{array}$} & 1.904 & -0.347 & 0.156 & -0.463 \\
\hline & $(3.028)$ & $(5.227)$ & $(5.406)$ & $(0.490)$ \\
\hline \multirow[t]{2}{*}{$\begin{array}{l}\ln \text { (fixed asset } \\
\text { investment) }\end{array}$} & 0.391 & -0.382 & -0.835 & -0.016 \\
\hline & $(0.323)$ & $(0.559)$ & $(0.580)$ & $(0.052)$ \\
\hline \multirow[t]{2}{*}{ urban ratio } & $1.655^{\star}$ & -2.433 & -2.238 & 0.158 \\
\hline & $(0.899)$ & $(1.591)$ & $(1.740)$ & $(0.145)$ \\
\hline \multirow[t]{2}{*}{ population growth rate } & 0.283 & 1.417 & 1.867 & -0.491 \\
\hline & $(1.906)$ & $(3.283)$ & $(3.406)$ & $(0.308)$ \\
\hline \multirow[t]{2}{*}{$\ln$ (population density) } & $1.112^{* * *}$ & $1.401^{\star}$ & 0.494 & -0.005 \\
\hline & $(0.415)$ & $(0.717)$ & $(0.742)$ & $(0.067)$ \\
\hline \multirow[t]{2}{*}{$\ln (\mathrm{PCDI})$} & 0.264 & -0.276 & 0.062 & $0.254^{*}$ \\
\hline & $(0.912)$ & $(1.575)$ & $(1.631)$ & $(0.148)$ \\
\hline \multirow[t]{2}{*}{$\ln$ (urban road area) } & $0.543^{\star *}$ & 0.008 & 0.241 & 0.009 \\
\hline & $(0.248)$ & $(0.439)$ & $(0.479)$ & $(0.040)$ \\
\hline city fixed effect & yes & yes & yes & yes \\
\hline time fixed effect & yes & yes & yes & yes \\
\hline $\begin{array}{l}\text { province specific } \\
\text { time trend }\end{array}$ & yes & yes & yes & yes \\
\hline \multirow[t]{2}{*}{ constant } & -73.941 & $230.750^{\star *}$ & 127.454 & $14.084^{*}$ \\
\hline & -50.318 & $(89.492)$ & $(93.030)$ & $(8.138)$ \\
\hline observations & 408 & 404 & 404 & 408 \\
\hline R-squared & 0.598 & 0.403 & 0.625 & 0.119 \\
\hline number of city & 46 & 46 & 46 & 46 \\
\hline
\end{tabular}

Note: we employ ${ }^{*}{ }^{* *}$ and ${ }^{* * *}$ respectively to denote the significance level $10 \%, 5 \%$ and $1 \%$ : we report the standard errors clustered at the province level.

\subsubsection{Career Incentive of a City Leader's Immediate Predecessor}

Additionally, policy continuity may benefit the economic development of a city. Therefore, a city leader may implement the land development and transfer policies that his immediate predecessors made. If the current leader's career incentive and his immediate predecessor's career incentive significantly correlates, we will have biased regression results. Considering that, we include the career incentive of immediate predecessor to avoid this problem. Table 6 shows the robustness check results; main results are still similar when the immediate predecessor's career incentive is controlled.

\subsubsection{Tenure Length}

A city leader with higher career incentive may stay in office for a comparatively 
Table 6. Regression results of immediate predecessor's career incentive is controlled.

\begin{tabular}{|c|c|c|c|c|}
\hline & $\ln$ (landarea_resi) & $\ln$ (landprice_resi) & ln(landrevenue_resi) & auction_ratio \\
\hline & (1) & (2) & (3) & (4) \\
\hline \multirow[t]{2}{*}{ career incentive } & $-1.145^{\star *}$ & $1.963^{* *}$ & $1.498^{*}$ & $0.209^{* * *}$ \\
\hline & $(0.472)$ & $(0.810)$ & $(0.842)$ & $(0.073)$ \\
\hline \multirow[t]{2}{*}{$\begin{array}{l}\text { career incentive of } \\
\text { predecessor }\end{array}$} & -0.496 & 0.164 & -0.252 & 0.013 \\
\hline & $(0.415)$ & $(0.710)$ & $(0.738)$ & $(0.063)$ \\
\hline \multirow[t]{2}{*}{ fiscal deficit ratio } & 0.230 & -0.803 & $2.579^{* * *}$ & 0.002 \\
\hline & $(0.526)$ & $(0.901)$ & $(0.934)$ & $(0.084)$ \\
\hline \multirow[t]{2}{*}{ GDP } & -0.484 & $2.844^{* *}$ & 1.855 & -0.064 \\
\hline & $(0.776)$ & $(1.332)$ & $(1.382)$ & $(0.124)$ \\
\hline \multirow[t]{2}{*}{ GDP growth rate } & 0.876 & -2.415 & -2.545 & -0.377 \\
\hline & (2.535) & $(4.351)$ & $(4.562)$ & $(0.406)$ \\
\hline \multirow{2}{*}{$\begin{array}{c}\text { proportion of } \\
\text { secondary industry }\end{array}$} & -2.181 & -5.721 & -7.671 & $-1.414^{\star \star}$ \\
\hline & $(3.557)$ & $(6.096)$ & (6.317) & $(0.570)$ \\
\hline \multirow{2}{*}{$\begin{array}{c}\text { proportion of } \\
\text { secondary industry }\end{array}$} & 2.022 & 0.078 & 0.790 & -0.525 \\
\hline & $(3.043)$ & (5.213) & $(5.395)$ & $(0.488)$ \\
\hline \multirow[t]{2}{*}{$\begin{array}{l}\ln (\text { fixed asset } \\
\text { investment) }\end{array}$} & 0.350 & -0.126 & -0.564 & -0.008 \\
\hline & $(0.331)$ & $(0.569)$ & $(0.591)$ & $(0.053)$ \\
\hline \multirow[t]{2}{*}{ urban ratio } & $1.626^{*}$ & -2.104 & -2.299 & 0.179 \\
\hline & $(0.904)$ & $(1.592)$ & $(1.745)$ & $(0.145)$ \\
\hline \multirow[t]{2}{*}{ population growth rate } & 0.565 & 2.276 & 3.057 & -0.450 \\
\hline & (1.913) & $(3.271)$ & (3.396) & $(0.306)$ \\
\hline \multirow[t]{2}{*}{$\ln$ (population density) } & $0.936^{*}$ & $2.862^{* * *}$ & $2.309^{* *}$ & -0.018 \\
\hline & $(0.550)$ & $(0.950)$ & $(0.984)$ & $(0.088)$ \\
\hline \multirow{2}{*}{$\ln (\mathrm{PCDI})$} & 0.280 & -0.324 & 0.042 & 0.237 \\
\hline & $(0.923)$ & $(1.582)$ & $(1.639)$ & $(0.148)$ \\
\hline \multirow[t]{2}{*}{$\ln$ (urban road area) } & $0.570^{* *}$ & 0.054 & 0.339 & 0.011 \\
\hline & $(0.249)$ & $(0.439)$ & $(0.480)$ & $(0.040)$ \\
\hline city fixed effect & yes & yes & yes & yes \\
\hline time fixed effect & yes & yes & yes & yes \\
\hline $\begin{array}{c}\text { province } \\
\text { specific time trend }\end{array}$ & yes & yes & yes & yes \\
\hline \multirow[t]{2}{*}{ constant } & -80.419 & $178.675^{*}$ & 58.274 & 11.371 \\
\hline & $(53.864)$ & (94.427) & (98.124) & (8.618) \\
\hline observations & 402 & 398 & 398 & 402 \\
\hline R-squared & 0.589 & 0.403 & 0.618 & 0.115 \\
\hline number of city & 46 & 46 & 46 & 46 \\
\hline
\end{tabular}

Note: we employ ${ }^{*}{ }^{* *}$ and ${ }^{* * *}$ respectively to denote the significance level $10 \%, 5 \%$ and $1 \%$; we report the standard errors clustered at province level 
longer time. Under this circumstance, a city leader's tenure length may affect the number and price of residential land parcel he sold. So, we include the city leader's tenure length and its squared term in our regression as another robustness check. Table 7 shows the robustness check results. The results still remain robust.

Table 7. Regression results of including the tenure length amd its square term of the leader.

\begin{tabular}{|c|c|c|c|c|}
\hline & $\ln$ (landarea_resi) & $\ln$ (landprice_resi) & $\ln$ (landrevenue_resi) & auction ratio \\
\hline & (1) & (2) & (3) & (4) \\
\hline \multirow[t]{2}{*}{ career incentive } & $-0.782^{\star}$ & $1.865^{* *}$ & $1.396^{*}$ & $0.202^{\star * *}$ \\
\hline & $(0.439)$ & $(0.769)$ & $(0.799)$ & $(0.073)$ \\
\hline \multirow[t]{2}{*}{ tenure length } & $-0.260^{* * *}$ & 0.064 & -0.158 & -0.004 \\
\hline & $(0.095)$ & $(0.167)$ & $(0.173)$ & $(0.016)$ \\
\hline \multirow[t]{2}{*}{ tenure length square } & $0.021^{* *}$ & -0.009 & 0.009 & 0.001 \\
\hline & $(0.009)$ & $(0.016)$ & $(0.017)$ & $(0.002)$ \\
\hline \multirow[t]{2}{*}{ fiscal deficit ratio } & 0.156 & -0.948 & $2.780^{\star * *}$ & 0.029 \\
\hline & $(0.522)$ & $(0.912)$ & $(0.948)$ & $(0.086)$ \\
\hline \multirow[t]{2}{*}{ GDP } & -0.321 & $2.903^{* *}$ & 2.110 & -0.098 \\
\hline & $(0.774)$ & $(1.354)$ & $(1.408)$ & $(0.128)$ \\
\hline \multirow[t]{2}{*}{ GDP growth rate } & 1.071 & -1.946 & -1.862 & -0.378 \\
\hline & $(2.503)$ & $(4.379)$ & $(4.605)$ & $(0.413)$ \\
\hline \multirow[t]{2}{*}{$\begin{array}{c}\text { proportion of } \\
\text { secondary industry }\end{array}$} & -2.237 & -6.336 & -8.316 & $-1.282^{\star *}$ \\
\hline & $(3.506)$ & $(6.125)$ & $(6.364)$ & $(0.580)$ \\
\hline \multirow{2}{*}{$\begin{array}{l}\text { proportion of } \\
\text { tertiary industry }\end{array}$} & 2.105 & -0.359 & 0.570 & -0.402 \\
\hline & $(3.013)$ & $(5.259)$ & $(5.453)$ & $(0.498)$ \\
\hline \multirow[t]{2}{*}{$\begin{array}{l}\text { ln (fixed asset } \\
\text { investment) }\end{array}$} & 0.310 & -0.359 & -0.879 & -0.022 \\
\hline & $(0.322)$ & $(0.564)$ & $(0.588)$ & $(0.053)$ \\
\hline \multirow[t]{2}{*}{ urban ratio } & 1.456 & -2.221 & -2.558 & 0.191 \\
\hline & $(0.892)$ & (1.598) & $(1.759)$ & $(0.148)$ \\
\hline \multirow[t]{2}{*}{ population growth rate } & 0.425 & 2.091 & 2.740 & -0.515 \\
\hline & $(1.957)$ & $(3.410)$ & $(3.549)$ & $(0.324)$ \\
\hline \multirow[t]{2}{*}{$\ln$ (population density) } & $1.079^{* * *}$ & $1.405^{\star}$ & 0.549 & -0.012 \\
\hline & $(0.415)$ & $(0.726)$ & $(0.753)$ & $(0.068)$ \\
\hline \multirow[t]{2}{*}{$\ln (\mathrm{PCDI})$} & 0.300 & -0.173 & 0.213 & $0.272^{*}$ \\
\hline & $(0.909)$ & $(1.590)$ & $(1.650)$ & $(0.150)$ \\
\hline \multirow[t]{2}{*}{ ln (urban road area) } & $0.441^{*}$ & -0.003 & 0.175 & 0.025 \\
\hline & $(0.245)$ & $(0.441)$ & $(0.483)$ & $(0.041)$ \\
\hline
\end{tabular}




\section{Continued}

\begin{tabular}{ccccc}
\hline city fixed effect & yes & yes & yes & yes \\
$\begin{array}{c}\text { time fixed effect } \\
\text { province specific } \\
\text { time trend }\end{array}$ & yes & yes & yes & yes \\
constant & yes & yes & yes & yes \\
observations & -57.593 & $234.000^{\star *}$ & 141.963 & 12.733 \\
R-squared & $(51.648)$ & $(93.237)$ & $(97.168)$ & $(8.554)$ \\
number of city & 0.606 & 401 & 401 & 405 \\
\hline
\end{tabular}

Note: we employ ${ }^{*}{ }^{* *}$ and ${ }^{* * *}$ respectively to denote the significance level $10 \%, 5 \%$ and $1 \%$; we report the standard errors clustered at the province level.

\section{Conclusion}

Residential land transfer is essential to consider because not only residential land sale revenue becomes one of the most important sources of off-budgetary income for China's local city governments but also it has significant impacts on China's economic development, urbanization and people's social welfare in the long run. This paper conducts a research on the impact of city leaders' career incentives on residential land transfer behavior of local governments. The empirical results show that one-standard-deviation increase in career incentive measure will result in $12.29 \%$ decrease in residential land transfer area, $27.35 \%$ increase in residential land price, $20.05 \%$ residential land revenue and $2.99 \%$ increase in the ratio of areas transferred through auction to all transferred residential land areas.

Local leaders whose career incentives are higher tend to manipulate the local residential land market more to boost local economic growth and improve their promotion likelihood. This behavior results in the undersupply of residential land and unreasonably higher price of residential land, which lead to the continuously rising housing price in China. The rocketing housing price causes welfare losses and has negative impacts on China's economic development in the long run. As a consequence, it is necessary to reform the local land market in China and make the supply of residential land be in line with the need of local residents.

Future research could be conducted in the following directions. It would be interesting to investigate how the residential land revenue affects the infrastructure provision behavior of local governments, and how this further affects local residents' welfare and industrial development. Meanwhile, commercial land is also transferred through public transaction, we could include commercial land into research.

\section{Conflicts of Interest}

The author declares no conflicts of interest regarding the publication of this paper. 


\section{References}

Brueckner, J. K., Fu, S., Gu, Y., \& Zhang, J. (2017). Measuring the Stringency of Land-Use Regulation: The Case of China's Building-Height Limits. The Review of Economics and Statistics, 99, 663-677. https://doi.org/10.1162/REST_a 00650

Cai, H., Henderson, J. V., \& Zhang, Q. (2013). China's Land Market Auctions: Evidence of Corruption? The RAND Journal of Economics, 44, 488-521. https://doi.org/10.1111/1756-2171.12028

Chen, T., \& Kung, J. K. (2019). Busting the "Princelings": The Campaign against Corruption in China's Primary Land Market. Quarterly Journal of Economics, 134, 185-226. https://doi.org/10.1093/qje/qjy027

Eckaus, R. S. (2003). Some Consequences of Fiscal Reliance on Extrabudgetary Revenues in China. China Economic Review, 14, 72-88. https://doi.org/10.1016/S1043-951X(03)00002-6

Fan, J., \& Mo, J. (2014). Local Government Debt, Land Market Institution and Regional Industrial Growth. Economic Research Journal, No. 1, 41-55. (In Chinese)

Han, L., \& Kung, J. K. (2015). Fiscal Incentives and Policy Choices of Local Governments: Evidence from China. Journal of Development Economics, 116, 89-104. https://doi.org/10.1016/j.jdeveco.2015.04.003

He, C., Huang, Z., \& Wang, R. (2014). Land Use Change and Economic Growth in Urban China: A Structural Equation Analysis. Urban Studies, 51, 2880-2898. https://doi.org/10.1177/0042098013513649

He, C., Zhou, Y., \& Huang, Z. (2016). Fiscal Decentralization, Political Centralization, and Land Urbanization in China. Urban Geography, 37, 436-457. https://doi.org/10.1080/02723638.2015.1063242

Huang, Z., \& Du, X. (2017). Strategic Interaction in Local Governments' Industrial Land Supply: Evidence from China. Urban Studies, 54, 1328-1346. https://doi.org/10.1177/0042098016664691

Li, H., \& Zhou, L. (2005). Political Turnover and Economic Performance: The Incentive Role of Personnel Control in China. Journal of Public Economics, 89, 1743-1762. https://doi.org/10.1016/j.jpubeco.2004.06.009

Lichtenberg, E., \& Ding, C. (2009). Local Officials as Land Developers: Urban Spatial Expansion in China. Journal of Urban Economics, 66, 57-64. https://doi.org/10.1016/j.jue.2009.03.002

Lin, G. C., \& Yi, F. (2011). Urbanization of Capital or Capitalization on Urban Land? Land Development and Local Public Finance in Urbanizing China. Urban Geography, 32, 50-79. https://doi.org/10.2747/0272-3638.32.1.50

Maskin, E., Qian, Y., \& Xu, C. (2000). Incentives, Information, and Organizational Form. The Review of Economic Studies, 67, 359-378. https://doi.org/10.1111/1467-937X.00135

Mo, J. (2018). Land Financing and Economic Growth: Evidence from Chinese Counties. China Economic Review, 50, 218-239. https://doi.org/10.1016/j.chieco.2018.04.011

Qian, Y., \& Xu, C. (1993). The M-Form Hierarchy and China's Economic Reform. European Economic Review, 37, 541-548. https://doi.org/10.1016/0014-2921(93)90043-A

Tao, R., Su, F., Liu, M., \& Cao, G. (2010). Land Leasing and Local Public Finance in China's Regional Development: Evidence from Prefecture-Level Cities. Urban Studies, 47, 2217-2236. https://doi.org/10.1177/0042098009357961

Wang, H., Zong, Q., \& Tao, J. (2013). Race to the Bottom: The Manufacturing Land 
Leasing Strategy of Municipal Governments in China. South China Journal of Economics, 31, 37-51.

Wang, Y., \& Hui, E. C. (2017). Are Local Governments Maximizing Land Revenue? Evidence from China. China Economic Review, 43, 196-215. https://doi.org/10.1016/j.chieco.2017.02.005

Wang, Z., Zhang, Q., \& Zhou, L. (2019). Career Incentives of City Leaders and Urban Spatial Expansion in China. The Review of Economics and Statistics, 1-45. https://doi.org/10.1162/rest a 00862

Wong, C., \& Bird, R. (2008). Fiscal System in China: A Work in Progress. In B. Loren, \& G. R. Thomas (Eds.), China's Great Economic Transformation (pp. 429-466). Cambridge: Cambridge University Press. https://doi.org/10.1017/CBO9780511754234.013

$\mathrm{Xu}, \mathrm{C}$. (2011). The Fundamental Institutions of China's Reforms and Development. Journal of Economic Literature, 49, 1076-1151. https://doi.org/10.1257/jel.49.4.1076

Yang, Z., Ren, R., Liu, H., \& Zhang, H. (2015). Land Leasing and Local Government Behavior in China: Evidence from Beijing. Urban Studies, 52, 841-856. https://doi.org/10.1177/0042098014529342

Yu, J., Xiao, J., \& Gong, L. (2015). Political Cycle and Land Leasing: Evidence from Chinese Cities. Economic Research Journal, No. 2, 88-102. (In Chinese)

Zhang, X., Wang, X., \& Xu (2011). Fiscal Incentive, Political Incentive and Local Officials' Land Supply. China Industrial Economy, No. 277, 25-43. 